\title{
Links between food price behaviour and nutrition in the developing world
}

\author{
Bethany Woods
}

\author{
This study was conducted under the supervision of Professor Getu Hailu, \\ Department of Food, Agriculture and Resource Economics, Ontario Agricultural College, \\ University of Guelph
}

\begin{abstract}
With the recent financial crisis and its enduring fallout, questions surrounding the state of global food security have become more pressing. A key element influencing the nutritional status of the world's poor is price behavior within global food commodity markets. In recent decades, food commodity markets have experienced both significant price increases, and an increase in volatility. These price trends have had significant impacts on the diversity of diets in impoverished households worldwide, which in turn has impacted nutrition and health. This paper will discuss the causes behind recent trends in food commodity prices, and the extent of their impact on food security and nutrition. Specifically, it will address the impact of food price increases and the uncertainty induced by food price volatility on household food consumption and nutrition. Micronutrient intake is the focus of the nutritional discussion of this work, and variations of consumption behavior in various regions and within different household dynamics are all taken into account. Existing policy actions are discussed in terms of the frequency of their implementation, the factors encouraging or deterring their implementation, and their intended and unintended consequences. Finally, the paper concludes with suggestions for future actions and areas for future research.
\end{abstract}

$\mathrm{F}$ ood insecurity is a growing problem in countries of the global South, in spite of significant aid efforts to end hunger. The recent economic crisis in 2008 and its aftermath has raised concern globally about rising levels of micronutrient malnutrition that are occurring among the world's poorest populations. These rising levels of malnutrition have negative implications not only for individual and household health, but also for future economic growth and development through the diminishment of human capital. Children who are malnourished can in many cases develop into less productive adults, and malnourished adults are less productive workers as well; this has strong negative implications for economic growth and development. Rising rates of micronutrient malnutrition are largely due to a decrease in the diversity of food consumption and a growing reliance on staples foods for energy within food insecure households. There are many factors at play that contribute to food access and food availability, but one important factor that has recently come to scholarly attention is the phenomenon of rising agricultural commodity prices.

During the first quarter of 2008, food prices reached their highest nominal and real levels in 50 and 30 years, respectively [1]. Though prices declined from 2008 peaks, the trend of rising food crop prices continues. This trend, and the occurrence of a second price spike in 2010, has led many economists to argue that both price volatility and price increases ${ }^{\mathrm{a}}$ should be expected to continue in the future [1-6].
The result will be an increase in food insecurity in the developing world, as the already strained food entitlements of the poorest are placed under increasing pressure. This paper will critically review the relationship between recent food price increases and volatility in food commodity markets, and nutrition in the world's poorest regions. First, casual factors in the food price crisis will be briefly discussed. Second, there will be a concise discussion of the existing literature on the nutritional impacts of these trends, with a focus on micronutrient deficiencies and their social, economic, and health consequences. Third, policy responses implemented by national governments will be described and evaluated. Finally, there will be a brief section listing suggested alternatives to these policy measures, and identifying areas for further research.

\section{CAUSES OF FOOD COMMODITY PRICE TRENDS}

The causes of recent food commodity price trends are complex and interlocking, and it is impossible to determine which factors are the most influential. Economists have identified both demand and supply-side causes in existing literature to be significant.

\section{Demand-Side Causes of Food Price Increases}

Leading up to the crisis in 2008, depreciation of the U.S. dollar made food commodity exports from the U.S. 
cheaper in the global market, increasing demand for U.S. grain crops [7]. Demand for biofuels has also risen substantially in recent decades due to rising fuel costs, concerns about the stability of energy supplies, and government financial and policy support $[8,9,3]$. It has been estimated by the International Food Policy Research Institute (IFPRI) that between 2000 and 2007, biofuel demand contributed to a $30 \%$ increase in weighted average grain prices, increasing maize, rice, and wheat prices by $39 \%, 21 \%$ and $22 \%$, respectively $[10,11,12]$.

Changing lifestyles in emerging economies (such as China and India) have also increased demand for food commodities. The purchasing power of these countries globally has reached the same level as the total purchasing power of consumers in the United States, and is continuing to rise [13]. By one estimate, by the year 2020 almost all of the increase in world food demand will come from developing countries [14]. Central to this phenomenon of growing demand is the process of urbanization, which is occurring rapidly in the global South [15]. Urbanization increases food accessibility and variety for individuals migrating to cities. The result is changing eating habits that are having a significant impact on food commodity markets; specifically, increases in fruit, vegetable, and meat consumption per capita $[16,17,18]$.

\section{Supply-Side Causes of Food Price Increases and Food Price Volatility}

An important supply-side cause of the short-term price volatility experienced in 2008 was adverse weather leading to poor harvests and the depletion of food stocks $[1,9]$. Long term price increases have been attributed to a variety of supply-side factors, the first being steadily rising fuel costs. The rise in fuel prices in recent years has increased both the cost of machinery operation and fertilizer for farmers, lowering output, and subsequently lowering stocks [1, 3, 9, $19,20]$. At the height of the food price spikes in the first two months of 2008, some fertilizer prices had increased by more than $160 \%$ [1]. Rising fuel costs combined with the depreciating U.S. dollar has widened the gap between supply and demand over time, leading to higher food prices [9]. However, rising production costs are not the only factor responsible for declining stocks.

Some economists have pointed to the Uruguay Round Agreements of the World Health Organization (WTO) as being an influential factor in stock reduction since the 1990s, as it influenced the size of reserves and the cost of storing perishables [1]. It has also been argued that stock reductions were largely policy induced; specifically, the result of changes in cereal stockholding strategies in China and the European Union [21, 22, 23]. Other scholars have blamed the dissolution of Soviet Union and its centralized economy for a significant portion of declining grain stocks [21].

In contrast, there is a large body of literature that argues that declines in agricultural productivity growth, or 'productivity plateaus', in global agricultural production are the main cause of stock depletion and rising prices $[6,14,19$, $22,24-26]$. The alleged productivity plateaus have been blamed on declining crop prices that have made it unattractive to invest in agricultural research and development (R\&D) in both the global North and South [25, $22,6,27]$. Economists also point to the shift in R\&D funding from public to private sources as being a factor in the movement away from research into productivity growth, toward areas like environmental and food safety concerns $[28,26]$. However, that agricultural productivity growth is declining is not universally accepted. A 2002 study using FAOSTAT data covering a period from 1961-1994 for twenty Less Developed Countries (LDCs) ${ }^{\mathrm{b}}$ found that sixteen countries experienced significant productivity growth, and only one experienced a decline [29]. Different economists have come to different conclusions regarding productivity trends in the developed and developing world, and this issue is still highly contested.

\section{Speculative Activity: Stabilizing or Volatility Inducing?}

Some economists argue that the increasing role of commodity index funds and over-the-counter derivatives ${ }^{c}$ in agricultural commodity futures markets have played a role in recent food price volatility $[20,30]$. Index-based derivative trade has grown significantly in the past few decades, as agricultural commodities have been seen as an investment option that provides protection against inflation and portfolio risk [31]. More recently, the subprime crisis in the U.S. led investors to look for alternative investment options, of which agricultural commodities have become a growing proportion [32]. As a result, many economists argue that commodity futures have come to be viewed as an asset class comparable to equities, bonds, and real estate, making food prices more vulnerable to volatility within financial markets $[33,30]$.

In contrast, there are many economists who posit that new forms of speculation provide greater liquidity to food commodity markets and increase market efficiency [33]. These economists argue that during the 2008 and 2010 price spikes, speculators were responding to fundamental changes in supply and demand conditions - not distorting market function, but reacting to changing market environments. Nevertheless, the correlation of the increase in new forms of speculative activity and price volatility should not be dismissed as coincidental, and requires further analysis.

\section{THE NUTRITIONAL COSTS OF PRICE INCREASES AND PRICE VOLATILITY}

The impact of rising food costs and food price volatility on the nutritional status of individuals and households is influenced by a variety of factors. First, it is important to distinguish between the effects of food price volatility and food price increases. Volatility tends to have much more immediate and severe (though often short-lived) impacts on nutritional intake in net food purchasing households ${ }^{\mathrm{d}}$, as these households have difficulty predicting and adjusting to 
food costs. In cases of sudden food price hikes, nutritional intake will suffer more than in cases of gradual and expected food price increases. Food security is a matter of food availability and food access, and the phenomena of rising food prices influences both the quantity of food available for consumption, and the accessbility of that food in terms of cost. It does this by altering consumption behaviour; namely, by decreasing household dietary diversification. This change in dietary diversification is an almost universal phenomenon, but there are important destinctions to be made at both the regional and national level, as well as the household level. Specifically, there are key differences between geographic regions, rural and urban areas, net buyers and sellers of food, and within households according to gender and power dynamics.

\section{Factors Influencing Household Consumption Behaviour}

Whether an increase in crop prices translates to an increase in food prices for an individual — and the magnitude of that increase - is dependent on the share of the consumer food dollar that goes to the farmgate, and the amount of disposable income that is spent on food [6]. In high income countries like the Canada, as little as one-fifth of the consumer food dollar goes to the farmgate, which lessens the severity of the impact of crop price increases on consumption. In contrast, developing country households spend upwards of $50 \%$ of their food dollar at the farmgate; with such a small distinction between crop price and food price, these households are far more severely impacted by food commodity price increases. Poor households in the global South also spend a much higher portion of their incomes on food than even the poorest housholds in the developed world. Thus, the impact of price changes on their ability to consume healthy food is significant.

In the short term, the impact of rising food prices on food consumption is also dependent on the position of the household as a net producer (seller) or a net consumer (buyer) of food [1]. In the past, it has been argued that low food prices are more harmful to the world's poor than rising food costs, as the world's poorest populations tend to be engaged in farming [34]. However, this assumes that the majority of farmers in the global South are net sellers of food, which is not the case. Even in rural areas where the majority of the population is involved in some form of farming, it is rare that households are net food producers [19]. These households usually depend on markets for some portion of their dietary intake, and also often do not have the flexibility to shift consumption to cheaper substitutes when prices rise, due to their market isolation.

The impact of rising food costs on dietary intake is also influenced by the specific commodities in question. Staple products such as cereals, fats, and oils have much lower income elasticities than meat and dairy products; thus the impact of rising prices for these products on consumption behaviour is less significant [17]. The difference in elasticities between lower value staples and higher value items (such as 'luxury' food items, like steak) exists regardless of income level, though the magnitude of the difference is more significant in lower income countries. Therefore, it can be hypothesized that households in poorer countries tend to make larger adjustments to their dietary diversity when faced with rising food prices [17, 6, 35]. A study by Guo et al. (1999) which investigated the impact of price increases on consumption behavour among rich and poor households in China supports this hypothesis [36]. Using longitudinal data from the first three rounds of the China Health and Nutrition Survey (CHNS), Guo et al. investigated two buying decisions affected by price change: 1) whether to consume a good, and 2) the quantity to consume. The study concluded that an increase in the price of each food group studied led to significant reductions in the probability of consuming any food within that group. It also concluded that the quantity of consumption was less significantly effected than nutritional value as prices increased, for both income groups. This tendency to reduce the quality of food consumed in times of hardship is concerning, given the nutritional impacts.

Given recent price events, decreasing dietary diversification is the gravest concern. Because the quality of food consumption among the poor will be reduced before quantity, it is micronutrient deficiencies and not starvation that are the expected outcome of recent food price trends in most areas [37, 6]. The impact of these micronutrient dificiencies will likely be felt the most by children, due to gender and household dynamics that make them more vulnerable (to be discussed below), and due to the impact of such nutritional deficiencies on their long term development. Studies have indicated that malnutrition during the first two years of a child's development has lifelong consequences for their ability to be productive adults [37]. Thus poor nutrition among very young children can be severely deterimental to the development of human capital within a country.

The impact of reduced dietary diversity on child nutritional status was demonstrated by a Bangladesh study conducted in 2003, which measured the relationship between staple food consumption and child malnutrition [38]. The study found a positive correlation between the percentage of underweight children and weekly rice consumption, and the opposite relationship for non-rice consumption. Higher rice consumption - and lower dietary diversity - was therefore correlated with poorer child nutrition. The authors concluded that greater dietary diversity was correlated with better child nutrition, and thus a decrease in dietary diversity due to rising prices of cereal staples will have serious impacts on child health in the developing world.

The World Food Program (WFP) documented widespread evidence of reductions in the quality and quantity of food consumption occuring globally while conducting household-level food security assessments in 2008 [37]. While global trends are helpful for gauging the extent of the issue, it is important to look at regional differences in 
consumption patterns as well, to better understand the impact of food price trends in different developing regions.

\section{Geography and Regional Trends}

According to WFP data, there are significant regional differences in food basket cost increases. It follows that there are also differences in the impacts of those price increases, due to geographic variations in consumption patterns. For example, within the continent of Africa there were vast differences in food basket price increases between 2007 and 2008, with West and Central Africa experiencing food cost increases of $20 \%$, and East and Southern Africa experiencing increases of up to $68 \%$ [37]. Differences in food basket price increases are largely due to dietary composition. Low income Asian and Subsaharan African countries have been hit especially hard as grains comprise upwards of $50 \%$ of traditional diets in these areas, and those staple prices have been rising drastically.

Regional differences in the trade behaviour of countries also impact their vulnerability to food price trends. New importing low income countries have been hit the hardest; specifically countries that depend on imports for more than $40 \%$ of their grain consumption such as Erierea, Niger, Liberia, Haiti and Botwana [6]. Domestic income inequality also plays an important role in food security. The food gap defined as the amount of food needed to raise per capita consumption to 2,100 calories - has increased the most in Latin America and the Caribbean due to recent food price trends [37], perhaps due to the severe levels of income inequality present in those areas. Overall, countries that will be the hardest hit in the long term are those that are net importers of both food and fuel (See Table 1).

\section{Rural Vs. Urban Food Security}

The urban poor and rural landless are the hardest hit when food prices increase [6, 1, 35]. It has been suggested that some rural dwellers in the developing world may be able to capitalize on rising food crop prices as producers. However, there are many barriers that make this highly unlikely. The majority of these individuals are smallholders farming on two hectares or less [19]. This form of smallholder farming provides up to $80 \%$ of food consumed in some developing regions, but these households are still most often net food buyers, and thus do not benefit from higher food crop prices. These farmers are also often limited by weak market integration and information systems, high transportation and transaction costs, and lack of adequate technologies and facilities for crop handling, processing, and storage. As a result, they are forced to sell immediately after harvest when prices are low, and to purchase food during lean periods when prices are high. Because production costs often increase with crop prices, even farmers who are net producers often do not benefit from increasing prices.

In urban areas, food production on any substatial scale is rare and more than $97 \%$ of households are net food buyers [35]. Because urban consumers have better market access
Table 1: Countries Facing Significant Threat from Rising Food Prices

\begin{tabular}{|c|c|c|c|}
\hline Countries & $\begin{array}{c}\text { Petroleum } \\
\% \\
\text { Imported }\end{array}$ & $\begin{array}{l}\text { Major Grains } \\
\% \text { Imported }\end{array}$ & $\begin{array}{c}\% \\
\text { Under- } \\
\text { nourish } \\
\text { ment }\end{array}$ \\
\hline Eritrea & 100 & 88 & 75 \\
\hline Burundi & 100 & 12 & 66 \\
\hline Comoros & 100 & 80 & 60 \\
\hline Tajikistan & 99 & 43 & 56 \\
\hline Sierra Leone & 100 & 53 & ?? \\
\hline Liberia & 100 & 62 & 50 \\
\hline Zimbabwe & 100 & 2 & 47 \\
\hline Ethiopia & 100 & 22 & 46 \\
\hline Haiti & 100 & 72 & 46 \\
\hline Zambia & 100 & 4 & 46 \\
\hline \multicolumn{4}{|l|}{ Central } \\
\hline Republic & 100 & 25 & 44 \\
\hline Mozambique & 100 & 20 & 44 \\
\hline Tanzania & 100 & 14 & 44 \\
\hline Guinea-Bissau & 100 & 55 & 39 \\
\hline Madagascar & 100 & 14 & 38 \\
\hline Malawi & 100 & 7 & 35 \\
\hline Cambodia & 100 & 5 & 33 \\
\hline Korea, DPR & 98 & 45 & 33 \\
\hline Rwanda & 100 & 29 & 33 \\
\hline Botswana & 100 & 76 & 32 \\
\hline Niger & 100 & 82 & 32 \\
\hline Kenya & 100 & 20 & 31 \\
\hline \multicolumn{4}{|c|}{$\begin{array}{l}\text { Source: Food and Agriculture Organization. 2008. Soaring food } \\
\text { prices: Facts, perspectives, impacts and actions required. Paper } \\
\text { presented at High-Level Conference on World Food Security: } \\
\text { The Challenges of Climate Change and Bioenergy, Rome. (pg } \\
\text { 17). }\end{array}$} \\
\hline
\end{tabular}

they are more likely to purchase imported foods, and as a result are more vulnerable to price fluctuations in international markets. While urban dwellers tend to have higher incomes than rural dwellers, because they are not food producers they do not have a 'buffer' against times of food price volatility. The urban dwellers are, however, the main target group for safety net programs in times of food crises, while rural dwellers are often denied access to these forms of support due to isolation and geographic dispersion [44]. Differences in rural and urban environments make both populations vulnerable to food price increases in different ways, and populations in both areas have very different mechanisms to cope with food price crises.

\section{Gender Imbalances and Nutritional Access}

Household power dynamics have a substantial influence on food consumption during times of food price increases, and 
thus have a significant impact on nutritional outcomes. There are important regional cultural variations in household structures, and in the dynamics between men and women. However, it can still be generalized that globally when food becomes more expensive, women and children tend to bear the brunt of the nutritional burden. Female headed households (FHHs) are at a particularly high risk, as they tend to have lower incomes on average and spend a much higher portion of their disposable income on food products $[35,1]$. FHHs in many regions of the global South also have less access to land, often due to gendered barriers to land ownership, and as a result cannot participate as producers in order to benefit from rising food prices [1].

That women and children are disproportionately impacted by volatility and increases in food prices is concerning, as the declining nutrition of pregnant women and children can have many long lasting negative impacts for not only individuals, but nations as well [37]. Micronutrient malnutrition in children can have severely detrimental impacts on cognitive development, that can diminish future human capital [6]. Additionally, poor maternal health resulting in inadequate energy intake and weight gain during pregnancy can cause poor fetal growth and decreased gestational duration [39]; this can lead to low birth weight and preterm birth. Low iron intake is especially dangerous for pregnant women, and it has been estimated that a $50 \%$ food basket price increase can result in as high as a $30 \%$ decrease in per capita iron intake [35]. Given that some areas of the world (as mentioned above) have faced food basket costs increases above $50 \%$, maternal wasting and anemia is an issue of grave concern. By one estimate, the recent food price crisis will increase rates of maternal anemia by $10-20 \%$ in at least East Asia and the Pacific [39].

The impact of decreased dietary diversity on child nutrition can be extreme. Even as much as six months of inadequate nutrition in the first two years of life can have severely detrimental impacts for an individual [37]. The largest disease burden associated with micronutrient deficiencies in children can be attributed to Vitamin $\mathrm{A}$ and Zinc [39]; research has indicated that vitamin A deficiency increases the risk of child mortality by $23-30 \%$, and zinc deficiency is associated with an increased risk of severe and persistent diarrhea, pneumonia, and stunting. Given that the International Food Policy Research Institute (IFPRI) associates malnutrition with $30 \%$ of infant deaths and considers it the single largest factor contributing to the global burden of disease [40], methods of mediating increases in

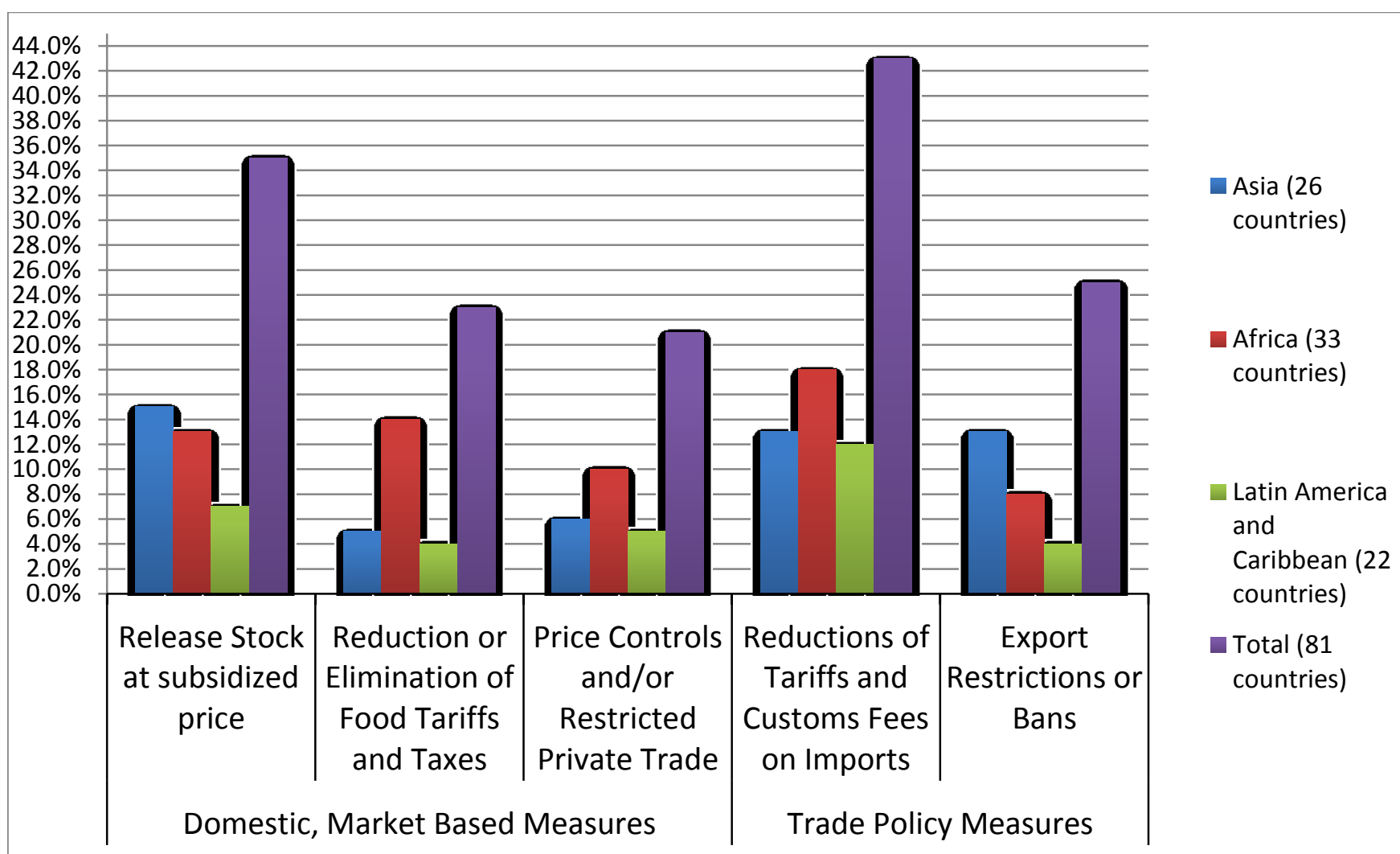

Figure 1: Percentage of Developing Countries Employing Market and Trade Based Policy Responses to Food Price Crisis in 2008 (From a Sample of 81). Source: Demeke, Mulat, Pangrazio, Guedalina and Materne Maetz. 2009. Initiative on Soaring Food Prices. Country Responses to the Food Security Crisis: Nature and Preliminary Implications of the Policies Pursued. FAO: Rome, Italy. (pg 7). 
child malnutrition should be the focus of future research and preventative policy.

\section{POLICY RESPONSES}

Policies in response to price volatility and price increases differ. State-led policy responses to crises brought on by food price volatility include trade restrictions and government support programs such as: stimulating food production in the short term through input subsidization and other support to farmers; export bans, taxes and restrictions; the lowering of tariffs and import taxes; price controls or consumer subsidies; and social safety net development [1, 19 , 5]. In response to long term price increases, are approaches focusing on a combination of welfare, and growth and development in the agricultural sector. Policy implementation varies regionally (See Tables 2 and 3 and Figures 1 and 2), depending on the geographic and economic context and which response is deemed most effective. These policy responses will be discussed and evaluated below.

\section{Subsidization and Trade Restrictions:}

Subsidies to producers for inputs such as fertilizer and seed are often implemented in an effort to stimulate production in the short-term, with the aim of increasing food availability [19]. This method can be successful if properly implemented, however subsidization programs are costly and require administrative capacity that many developing nations lack. Export bans are the most extreme response to food price increases, and are enacted with the intention of keeping food supplies within their producing countries to protect against shortages and ensure that the population has access to sustenance at an accessible price level [19, 41]. These bans have proven to be extremely detrimental to food commodity markets, as they can result in higher world prices and panic due to hoarding. Humanitarian organizations also have much more trouble procuring food for aid when export bans are in place, which makes it difficult to get emergency food supplies to the most vulnerable. Export taxes and other export restrictions have a similar effect, and though they are not quite as destabilizing as bans, the general consensus among policy analysts is that they should be avoided.

Another frequently implemented policy response to rising food prices is to lower tariffs and import taxes on food. This measure can be distorting, as it can lead to more consumption when food prices are high, accelerating real price increases in the global market [19]. These tariff decreases are also usually not permanent (as the WTO has caveats allowing countries to temporarily adjust tariffs for food security reasons), resulting in market signals becoming muddled when prices decline and the tariffs are re-applied. There can also be a significant fiscal cost when implementing this measure, as governments lose tariff revenue at a time when they are often also attempting to implement various forms of social protection [5]. An

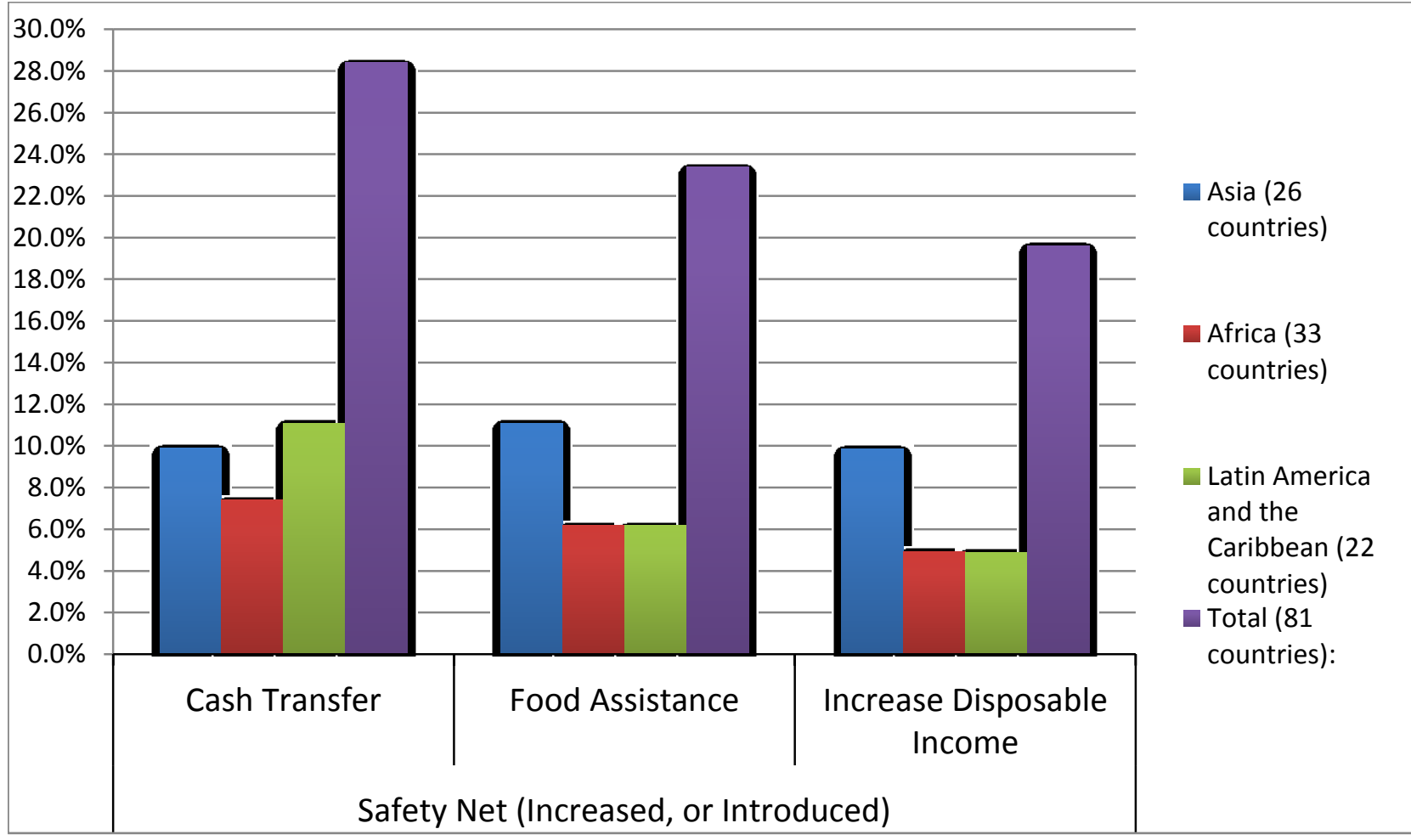

Figure 2: Percentage of Developing Countries Implementing Safety Net Responses to Food Crisis in 2008 (From a Sample of 81). Source: Demeke, Mulat, Pangrazio, Guedalina and Materne Maetz. 2009. Initiative on Soaring Food Prices. Country Responses to the Food Security Crisis: Nature and Preliminary Implications of the Policies Pursued. FAO: Rome, Italy. (pg 13). 
Table 2: Percentage of Developing Countries Employing Market and Trade Based Policy Responses to Food Price Crisis in 2008 (From a Sample of 81)

\begin{tabular}{|c|c|c|c|c|c|}
\hline & \multicolumn{3}{|c|}{ Domestic, Market Based Measures } & \multicolumn{2}{|c|}{ Trade Policy Measures } \\
\hline & $\begin{array}{c}\text { Release } \\
\text { Stock at } \\
\text { subsidized } \\
\text { price (\%) }\end{array}$ & $\begin{array}{l}\text { Reduction } \\
\text { or } \\
\text { Elimination } \\
\text { of Food } \\
\text { Tariffs and } \\
\text { Taxes (\%) }\end{array}$ & $\begin{array}{c}\text { Price } \\
\text { Controls } \\
\text { and/or } \\
\text { Restricted } \\
\text { Private } \\
\text { Trade }(\%)\end{array}$ & $\begin{array}{l}\text { Reductions } \\
\text { of Tariffs } \\
\text { and } \\
\text { Customs } \\
\text { Fees on } \\
\text { Imports } \\
(\%)\end{array}$ & $\begin{array}{c}\text { Export } \\
\text { Restrictions } \\
\text { or Bans } \\
(\%)\end{array}$ \\
\hline $\begin{array}{l}\text { Asia (26 } \\
\text { countries) }\end{array}$ & 15.0 & 5.0 & 6.0 & 13.0 & 13.0 \\
\hline $\begin{array}{l}\text { Africa (33 } \\
\text { countries) }\end{array}$ & 13.0 & 14.0 & 10.0 & 18.0 & 8.0 \\
\hline $\begin{array}{l}\text { Latin } \\
\text { America } \\
\text { and } \\
\text { Caribbean } \\
\text { (22 }\end{array}$ & & & & & \\
\hline countries) & 7.0 & 4.0 & 5.0 & 12.0 & 4.0 \\
\hline $\begin{array}{l}\text { Total (81 } \\
\text { countries) }\end{array}$ & 35.0 & 23.0 & 21.0 & 43.0 & 25.0 \\
\hline
\end{tabular}

Source: Demeke, Mulat, Pangrazio, Guedalina and Materne Maetz. 2009. Initiative on Soaring Food Prices. Country Responses to the Food Security Crisis: Nature and Preliminary Implications of the Policies Pursued. FAO: Rome, Italy. (pg 13).

alternative preventative method is the use of price controls or subsidies to prevent crop price increases from reaching vulnerable consumers [19,5]. These policy responses are arguably the most effective and equitable, as they target populations in need. However many countries lack the capacity to run such programs.

\section{Social Safety Net Responses:}

Emergency aid, social protection measures, and social safety nets are commonly used to mitigate the impact of food prices crises. These can come in many forms, ranging from food stamp programs, to targeted cash transfers, food for work programs, and emergency food aid distribution $[19,5]$. If properly targeted these programs can be extremely effective. However, much like the subsidization programs discussed above, such programs are expensive to implement and many governments lack the capacity to put them in place. They are also not sustainable in the long term as they often depend on a balance of payments deficit and external aid.

\section{The Twin Track Approach:}

In responding to rising food prices, national governments have been encouraged by international organizations to protect the welfare of the most poor and food insecure, while also providing public resources and designing policies and programmes to support renewed growth and development in the agricultural sector. This has been dubbed the "twin track approach" by the Food and Agriculture Organization of the UN (FAO), the International Fund for Agricultural Development (IFAD) and the WFP, and was first introduced at the Monterrey Conference on Financing for Development, and at the World Food Summit [1]. In spite of this framework, policy responses to date have focused mainly on immediate crisis response and have ignored the element of long term growth and development in agriculture.

\section{SUGGESTIONS FOR LONG-TERM SOLUTIONS}

Policy responses to the food crisis thus far have mainly been focused on crisis prevention or management, and have not been structured to address the roots of the issue. In order to make food accessible to the poor in the future, policies need to be targeting the underlying causes of recent food price trends, and they need to be focused on long

Table 3: Percentage of Developing Countries Implementing Safety Net Responses to Food Crisis in 2008 (From a Sample of 81 )

\begin{tabular}{lccc}
\hline & $\begin{array}{c}\text { Cash } \\
\text { Transfer } \\
(\%)\end{array}$ & $\begin{array}{c}\text { Food } \\
\text { Assistance } \\
(\%)\end{array}$ & $\begin{array}{c}\text { Increase } \\
\text { Disposable } \\
\text { Income } \\
(\%)\end{array}$ \\
\hline $\begin{array}{l}\text { Asia (26 } \\
\text { countries) }\end{array}$ & 9.9 & 11.1 & 9.9 \\
\hline $\begin{array}{l}\text { Africa (33 } \\
\text { countries) }\end{array}$ & 7.4 & 6.2 & 4.9 \\
\hline $\begin{array}{l}\text { Latin } \\
\text { America } \\
\text { and the }\end{array}$ & & & \\
$\begin{array}{l}\text { Caribbean } \\
\text { (22 }\end{array}$ & & & \\
countries) & 11.1 & 6.2 & 4.9 \\
\hline $\begin{array}{l}\text { Total (81 } \\
\text { countries): }\end{array}$ & 28.4 & 23.4 & 19.6 \\
\hline
\end{tabular}

Source: Demeke, Mulat, Pangrazio, Guedalina and Materne Maetz. 2009. Initiative on Soaring Food Prices. Country Responses to the Food Security Crisis: Nature and Preliminary Implications of the Policies Pursued. FAO: Rome, Italy. (pg 13). 
term structural change. There are several areas that should be considered by policy makers looking to improve food security; this paper will discuss: renewed investment in $\mathrm{R} \& \mathrm{D}$, new forms of risk management, the possibility of speculative regulation, changes to biofuel production regulation, the development of urban agriculture, and the promotion of trade liberalization.

\section{Research and Development}

Improving agricultural $R \& D$ should be the main focus of policymakers working to avoid the acceleration of food insecurity in the future. Currently, productivity focused agricultural R\&D is grossly lacking. For example, only $0.5 \%$ of Africa's agricultural GDP is spent on research to improve productivity [2]. While there is a significant lag time between initial investment and realization of returns that makes agricultural R\&D less attractive than other forms of investment, hundreds of cost-benefit analyses have reported that agricultural R\&D yields high returns in the long-term [26]. Poor smallholder farmers in the developing world do not have the capacity to make these investments themselves, as market imperfections limit access to credit and capital [42]. Thus to stimulate research and development public investment will be needed, and measures such as levies, tax credits, and subsidies will be necessary [28]. There is also a need to increase support to international funding bodies like the Consultative Group on International Agricultural Research (CGIAR) and the Global Agriculture and Food Security Program (GAFSP), and to encourage responsible foreign direct investment (FDI) [19]. The majority of R\&D needs to be focused on smallholders specifically, as technology and policies that are biased against smallholders can have a perverse effect on poverty [19, 42]. Because smallholders tend to be more risk-averse and unlikely to adopt techniques that increase yield variance, it is important to improve risk management as well [42].

\section{Risk Management}

Risk management is increasingly important as weather shocks become more and more frequent due to changing climates. Many developing countries already have temperatures that are near or above crop tolerance levels, and they are predicted to suffer an average of 10-15 percent decline in productivity by the 2080s (assuming that greenhouse gas emissions continue to increase as they have been) [43]. Developing countries also suffer the majority of the world's natural disasters [44]. Consequently, price volatility due to weather shocks can be expected to escalate in the future, and forms of weather risk management will become increasingly necessary. The implementation of weather risk management will require government coordination, institutions established at the national level for facilitation, and precise meteorological data [19]. Payouts should be used to finance food imports, social safety nets, and other forms of food security support.

\section{Speculative Regulation}

There is still much debate surrounding the nature of speculative activity, and its role in stabilizing global agricultural markets. Various critics have made suggestions as to how to better regulate speculation, including: regulation of authorized traders, the introduction of a trade register at stock exchanges, and the elimination of what has been labeled as particularly 'dangerous' speculation - namely hedge fund activity, and over the counter derivatives [20]. Some regulatory steps have already been taken by the Commodity Futures Trading Commission (CFTC) since the signing of the Dodd Frank Act in July of 2010. In contrast to the views of critics, there are also many scholars who do not see existing speculative activity as detrimental to food price stability, and argue that further regulation is not warranted [31]. While both sides can agree that speculative behaviour has the potential to play an important role in food price stabilization, the degree of regulation needed is widely contested. Communication between scholars on both sides of the debate, and an ongoing dialogue about the role of speculation in commodity price stabilization, is needed to continue to address this complex issue.

\section{Revisions to Biofuel Production}

The sustainability of biofuel production as it currently exists needs to be seriously reconsidered. Specifically, currently existing subsidies that make first generation biofuels competitive and increase the correlation between fuel and food crops, need to be reevaluated $[1,19,10]$. There are three specific policy suggestions that appear consistently in the literature on this issue: a shift in feedstock use [9, 44, 11], the development of second generation technology [46], and the opening of biofuel trade [9, 19]. Non-edible energy crops (for example, jatropha) that do not compete with food crops and can be grown on marginal lands should be substituted for current feedstocks $[9,11]$. As the poor often live on marginal lands, production of biofuels with these feedstocks actually has the potential to elliviate poverty without the negative food price impacts [11]. Second generation technology, such as technology that can produce biofuels from cellulose, needs to be developed before it will become economically, socially, and environmentally sustainable for many countries to participate in biofuel production [12]. Trade barriers in biofuel markets need to be removed as well, and international markets should be opened so that biofuels can be produced where it makes economic sense, and traded freely [19]. The removal of tariffs, specifically the current tariff in the United States, would lead to biofuels being produced from the lowest cost source which would reduce pressure on corn prices [11]. With all of these revisions, biofuel production could make a significant contribution to renewable energy in the future without jeapordizing global food security. 


\section{Urban Agriculture}

The importance of urban agriculture in many areas of the developing world (specifically, Subsaharan Africa) needs to be acknowledged and incorporated into future policy considerations. Urban agricultural development not only targets the urban poor - the most vulnerable category in the face of a food price crisis, along with the rural landless - but also women and children, who are generally at the highest risk of food insecurity and malnutrition within their households. Up to $40 \%$ of some Africa city populations are urban or peri-urban agriculturalists, and the percentage is as high as $50 \%$ in some Latin American cities [35, 47]. It is estimated that 200 million city dwellers produce food for urban markets, accounting for $15-20 \%$ of global food production. Many urban agriculturalists are women, and in many areas women make up the majority of urban farmers $[35,48]$. That women have such a significant presence within the urban agricultural movement makes urban agriculture an important area for future research and policy.

There are many reasons aside from gender benefits that provide impetus for the development of urban agriculture in the future. The majority of households that participate in urban farming do so to improve food access, improve household food supply and nutrition, and to supplement their incomes [49]. Urban agricultural production has been correlated with both dietary diversity and kilocalorie consumption [47]. It can also provide city dwellers with a buffer against seasonality and food shortages. Urban agriculture also provides opportunity for modernization because of market proximity, and the ease of extension and information dissemination due to population density [48]. There is, therefore, a potential for agricultural $R \& D$ to occur at an accelerated rate in urban settings.

In spite of these many benefits, urban farming is still part of the informal economy in most areas, and faces hostility from policymakers [35]. Scholars in support of urban agriculture have made many policy suggestions, including: encouraging backyard farming, making parcels of land available specifically for the poor and FHHs, providing support and extension, and providing marketing support [48]. Overall, urban agriculture needs to be moved into the formal economy so that farmers can receive the full benefit of their labour [35].

\section{Trade Liberalization}

Trade policies need to be improved to remove barriers to trade that increase food price distortion [1]. Potential market instabilities caused by domestic production fluctuations can be offset by trade, and studies have indicated that food supplies can be stabilized much more cheaply by trading in world markets than by domestic storage and buffer stocks $[23,19]$. This is because production at the aggregate level is much more stable than at the national or regional level, where agriculturally adverse weather or crop failure is more highly concentrated. In order to take advantage of the benefits of trade, however, countries need to reduce their tendencies to isolate themselves during food price crises [19]. An important step in eliminating these isolationist tendencies, which has been indentified by many scholars, is the completion of the WTO Doha Round discussions $[6,19]$.

\section{IMPORTANT AREAS FOR FUTURE RESEARCH}

While literature addressing various aspects of the emerging food crisis has been expanding over the past few years, there are still many gaps yet to be addressed by existing scholarship. The value of urban agriculture and its impact on mediating the effects of the food price crisis is still largely unknown. There is a lack of quantitative data on this subject; this is largely due to the fact that urban agriculture exists in the informal sector in most areas of the developing world, and much of the existing literature takes an advocacy stance that is not objective. Further research on the impact of this activity on household food security would be beneficial.

The ways in which rising food prices are related to violence and political instability could be better understood, in order to help policymakers develop preventative programmes. Food price riots will be likely to continue in the future as further price volatility is predicted, and violence prevention in the face of this instability should be a priority.

The ways in which issues relating to gender interact with food security issues is an area that has not received much academic attention, and the ways in which gendered entitlements affect household coping mechanisms in food crisis situations could be better understood. Specifically, the difference between how male and FHHs mediate the impacts of food price increases could help shed light on the gendered aspect of food insecurity.

Finally, while several governments have recently reintroduced food price stabilization initiatives, there is evidence that such initiatives do not benefit - and could in fact harm - the poorest households and most vulnerable population subgroups [50]. Very little is understood about the mechanisms and magnitude of the effects of macroeconomic food policies on nutritional status. Further research in this area is needed, specifically on the impact of food price stabilization initiatives on child and maternal nutrition.

\section{CONClusion}

The trend of rising agricultural commodity prices is likely to continue in the future. Given the nature of agricultural production and recent trends, some level of volatility is to be expected as well. As incomes and populations in the global South continue to expand, and as the planet continues to be impacted by rising temperatures and more frequently occuring adverse weather events, a focus on productivity enhancing agricultural R\&D becomes increasingly important. A focus on investment in agricultural $\mathrm{R} \& \mathrm{D}$, as well as subsidization programs to protect the 
poorest and most vulnerable populations from micronutrient malnutrition, should replace market interventions that only create further price distortion. The trend among developed countries of undervaluing agriculture as a sector needs to be reversed, as wealthier countries - especially the United States and Canada - have the resources to improve agricultural productivity in the future. International research bodies such as CGIAR and GAFSP also have a significant role to play in spreading knowledge globally, and building capacity in developing countries to implement new and effective technologies.

\section{ACKNOWLEDGEMENTS}

This research was completed as part of an Undergraduate Research Assistantship with the Department of Food, Agriculture and Resource Economics, under the supervision of Professor Getu Hailu. The author would like to thank Professor Hailu for his advice, support, and manuscript review.

\section{REFERENCES}

1. FAO. 2008. Soaring food prices: facts, perspectives, impacts and actions required. Paper presented at HighLevel Conference on World Food Security: The Challenges of Climate Change and Bioenergy, Rome.

2. Tweeten, L., and S. R. Thompson. 2009. Long-term global agricultural output supply-demand balance and real farm and food prices. Farm Policy Journal 6(1): 116.

3. Deaton, B. (Host). (2011, July 4). Food Prices. Food, Agriculture and Resource Economics Podcast. Podcast retrieved from http://fare.uoguelph.ca/Food-Prices.mp3.

4. Webb, P. 2010. Medium- to long-run implications of high food prices for global nutrition. The Journal of Nutrition 140 (1) (January): 1435-75.

5. PREM, ARD and DEC. 2008. Rising food prices: policy options and World Bank response. The World Bank: (Washington, DC). Accessed May 172011 from http://siteresources.worldbank.org/NEWS/Resources/ris ingfoodprices_backgroundnote_apr08.pdf

6. Weersink, A., Hailu, G., Fox, G., Meilke K.D. and M. von Massow. 2008. The World Food Crisis: Causes and Implications for Ontario Agriculture. Working Paper, January 2008. Department of Food, Agriculture and Resource Economics: University of Guelph.

7. Charlebois, P. and N. Hamann. 2010. The Consequences of a Strong Depreciation of the U.S. Dollar on Agricultural Markets [Electronic Version]. Ottawa: Research and Analysis Directorate, Agriculture and Agri-Food Canada. 12pp. Retrieved from http://publications.gc.ca/collections/ collection_2011/agr/A38-4-21-2010-eng.pdf.

8. Runge, C. $\bar{F}$. and B. Senauer. 2007. How biofuels could starve the poor. Foreign Affairs, 86 (?): 41-53.
9. Abbot, P.C., Hurt, C. and W.E. Tyner. 2008. Issue Reports, 37951. Farm Foundation.

10. Rosegrant, M. W. 2008. Biofuels and grain prices: Impacts and policy responsesInternational Food Policy Research Institute Washington, DC.

11. Ewing, M. and S. Msangi. 2009. Biofuels production in developing countries: assessing tradeoffs in welfare and food security. Environmental Science and Policy, 12(4): 520-528.

12. Von Braun, J. 2008. Biofuels, international food prices, and the poor. Testimony to the United States Senate Committee on Energy and Natural Resources, June 2008. Washington(DC): International Food Policy Research Institute (IFPRI).

13. Reusswig, F., Lotze-Campen, H. and K. Gerlinger. 2005. Changing global lifestyle and consumption patterns: The case of energy and food [online]. Retrieved May 25 2011, from http://www.Populationenvironmentresearch.org/ papers/Lotze-Campen_Reusswig_Paper.Pdf.

14. Pinstrup-Andersen, P., Pandya-Lorch, R. and M.W. Rosegrant. 1999. World food prospects: Critical issues for the early twenty-first century. 2020 Vision: Food Policy Report. Washington(DC): International Food Policy Research Institute.

15. McDonald, R. 2008. Global urbanization: is there a sustainable way forward? Frontiers in Ecology and the Environment, 6(2): 99-104.

16. Delgado, C.L. 2003. Rising consuption of meat and milk in developing countries has created a new food revolution. The Journal of Nutrition, 133 (11): 3907S3910S.

17. Regmi, A. 2001. Introduction. In, Changing Structure of Global Food Consumption and Trade. Pp 1-3. Regmi, A., Deepak, M.S., Seale J.L., and J. Bernstein, Eds. Washington(DC): USDA.

18. Regmi, A., and J. Dyck. 2001. Effects of urbanization on global food demand. In, Changing Structure of Global Food Consumption and Trade: 23-30. Regmi, A., Deepak, M.S. Seale J.L., and J. Bernstein Eds. Washington(DC): USDA.

19. FAO, IFAD, IMF, OECD, UNCTAD, WFP, the World Bank, WTO, IFPRI, and UN HLTF. 2011. Price volatility in food and agricultural markets: Policy responses. Retrieved June 17 2011, from http://www.oecd.org/document/2 0/0,3746, en $26493740148152724 \quad 1 \quad 1 \quad 1 \quad 37401,00$. html.

20. Wahl, P. 2009. Food speculation: The main factor of the price bubble in 2008. WEED - Weltwirtschaft, Ökologie \& Entwicklung, Briefing Paper. Berlin(Germany) WEED. Retrieved May 20 2011, from http://www2.weed-online.org/uploads/weed food_speculation.pdf.

21. Rosegrant, M.W., N. Leach, and R.V. Gerpacio. 1999. Alternative futures for world cereal and meat 
consumption. Proceedings of the Nutrition Society 58(02): 219-234.

22. Tangermann, S. 2011. Policy solutions to agricultural market volatility: A synthesis (Issue 33). Geneva, Switzerland: International Centre for Trade and Sustainable Deveopment (ICTSD). Retrieved June 20 2011, from http://ictsd.org/downloads/2011/ 06/tangermann-price-volatility-and-policy-options.pdf.

23. Makki, S.S., Tweeten, L.G. and M.J. Miranda. 2001. Storage-trade interactions under uncertainty: implications for food security. Journal of Policy Modeling, 23(2)(July): 127-140.

24. Fuglie, K.O. 2008. Is a slowdownin agricultural productivity growth contributing to the rise in commodity prices? Agricultural Economics, 39(s1): 431-441.

25. Tweeten, L., and S.R. Thompson. 2009. Long-term global agricultural output supply-demand balance and real farm and food prices. Farm Policy Journal, 6(1): 116.

26. Alston, J.M., Beddow, J.M. and P.G. Pardey. 2009. Agricultural research, productivity, and food prices in the long run. Science, 325(5945): 1209-1210.

27. Rosen, S. and S. Shapouri. 2007. Rising food prices and intensifying food insecurity in developing countries. Amber Waves, 6(1)(June): 16-21.

28. Gray, R. 2011. The future of crop research in canadaoptions and consequences [presentation]. Paper presented at First Annual Canadian Agriculture Policy Conference, Ottawa Ontario: Chateau Laurier. Retrieved from http://www.uoguelph.ca/catprn/PDFPres/gray-network-jan2011.pdf.

29. Nin, A., Arndt, C. and P.V. Preckel. 2003. Is agricultural productivity in developing countries really shrinking? New evidence using a modified nonparametric approach. Journal of Development Economics, 71(2): 395-415.

30. Gilbert, C.L. 2007. Commodity speculation and commodity investments. Revised version of the paper presented at the Conference on The Globalization of Primary Commodity Markets: Stockholm (October 2007).

31. Tang, K. and W. Xiong. 2010. Index Investment and Financialization of Commodities [Electronic Version]. Working Paper 09/10. National Bureau of Economic Research: Cambridge, MA. Retrieved from http://papers.ssrn.com.subzero.lib.uoguelph.ca/sol3/pap ers.cfm?abstract_id=1683135.

32. Steinberg, S. 2008. Financial speculators reap profits from global hunger [Electronic Version]. Centre for Research on Globalization: Montreal, QC. Retrieved from

http://globalresearch.ca/index.php?context=va\&aid=87 94

33. Clapp, J. and E. Helleiner. 2010. Troubled futures? The global food crisis and the politics of agricultural derivatives regulation. Review of International Political Economy, 99999(1): 1-27.

34. Swinnen, J.F.M. and P. Sqicciarini. 2012. Mixed Messages on Prices and Food Security. Science, 335(6067): 405-406.

35. Cohen, M.J., and J.L. Garrett. 2010. The food price crisis and urban food (in)security. Environment and Urbanization 22(2): 467-482.

36. Guo, X., Popkin, B.M. Mroz, T.A. and F. Zhai. 1999. Food price policy can favourably alter micronutrient intake in China. The Journal of Nutrition, 129(5): 9941001.

37. Brinkman, H., de Pee, S., Sanogo, I. Subran, L. and M.W. Bloem. 2009. High food prices and the global financial crisis have reduced access to nutritious food and worsened nutritional status and health. The Journal of Nutrition, 140(1): 153S-161S.

38. Torlesse, H., Kiess, L. and M.W. Bloem. 2003. Association of household rice expenditure with child nutritional status indicates a role for macroeconomic food policy in combating malnutrition. The Journal of Nutrition, 133(5): 1320-1325.

39. Christian, P. 2010. Impact of the economic crisis and increase in food prices on child mortality: Exploring nutritional pathways. The Journal of Nutrition 140(1)(January): 177S-181S.

40. Headey, D. 2011. Turning economic growth into nutrition sensitive growth (advanced copy). Paper presented at 2020 Conference: Leveraging Agriculture for Improving Nutrition and Health, New Delhi.

41. Dollive, K. 2008. The impact of export restraints on rising grain prices. Washington(DC): U.S. International Trade Commission. Retrieved May 172011 from http://usitc.gov/publications/332/working_papers/EC20 0809A.pdf.

42. Irz, X. Lin, L., Thirtle, C. and S. Wiggins. 2001. Agricultural productivity growth and poverty alleviation. Development Policy Review, 19(4): 449466.

43. Cline, W.R. 2007. Global warming and agriculture: Impact estimates by country. Danvers(MA): Peterson Institute.

44. Hess, U., Richter, K., and A. Stoppa. 2002. Weather risk management for agriculture and agri-business in developing countries. In Climate risk and the weather market. Pp. 1-16. London(UK): Risk Books. Retrieved May $20 \quad 2011$, from http://www.fao.org/uploads/media/Weather\%20Risk $\% 2$ 0Management $\% 20$ for $\% 20$ Agriculture $\% 20$ and $\% 20$ AgriBusiness\%20in\%20Developing\%20Countries.pdf.

45. Schmidhuber, J. 2008. Impact of an increased biomass use on agricultural markets, prices and food security: A longer-term perspective. Paper presented at the Conference Energy Security in Europe, September 2007. Lund(Sweden): Lunds Universitet. 
46. Pin Koh, L. and J. Ghazoul. 2008. Biofuels, biodiversity, and people: understanding the conflicts and finding opportunities. Biological Conservation, 141(10): 2450-2460.

47. Zezza, A., and L. Tasciotti. 2010. Urban agriculture, poverty, and food security: empirical evidence from a sample of developing countries. Food Policy, 35(34): 265-273.

48. Lee-Smith, D. 2010. Cities feeding people: an update on urban agriculture in equatorial Africa. Environment and Urbanization, 22(2): 483-499.
49. Kutiwa, S., Boon, E., and D. Devuyst. 2010. Urban agriculture in low income households of harare: An adaptive response to economic crisis. Journal of Human Ecology 32(2): 85-96.

50. Bellemare, M.F., Barrett, C.B. and D.R. Just. 2011. The welfare impacts of commodity price volatility: evidence from rural Ethiopia. Working Paper, 01/11. Retrieved from:

http://papers.ssrn.com/sol3/papers.cfm?abstract_id=154 4172 .

\section{ENDNOTES}

${ }^{a}$ Price volatility and price increases are two separate but connected phenomenon. The term 'price volatility' refers to short term fluctuations or deviations in prices either above or below the norm. In contrast, the phenomenon of rising prices occurs steadily over the long term, and is far more predictable.

b The label of 'Least Developed Country' is a category defined and applied by the UN to a nation that exhibits the lowest socioeconomic development indications and Human Development Index ratings in the world. A country is placed in this category if it's GNI falls below \$905USD, and also if it's indicators for nutrition, health, education and literacy indicate human resource weakness. Economic vulnerability is also considered, and is evaluated based on the instability of agricultural production, export goods and services, the economic importance of non-traditional activities, the concentration of merchandise in exports, economic smallness and the percentage of the population displaced by natural disasters.

c Over-the-counter derivatives are unregulated derivatives that are traded directly between two parties, and not through a mediating trade regulating body. These types of derivatives increased by $160 \%$ between 2005 and 2007 [20], leading many economists to argue that their growing prevalence is inked to the food price volatility that occurred around the same time. In June of 2008, the FAO argued that futures prices for wheat and maize were $60 \%$ and $30 \%$ beyond their expected underlying values, respectively, linking this phenomena to rising food prices [33].

${ }^{\mathrm{d}}$ In contrast to net food selling households, who actually benefit from temporary food price hikes. Depending on the status of a household as a net buyer or seller of food, volatility can have a positive or negative impact. 